\title{
Occupational Competencies Required By Retirees In Pawpaw Production And Marketing For Sustainable Livelihood In Enugu State, Nigeria.
}

\author{
Ernest O. Ugwoke ${ }^{1}$, Francis M. Onu ${ }^{2}$, Matthias U. Agboeze ${ }^{3} \&$ \\ Vincent C. Asogwa ${ }^{4}$ \\ ${ }_{1 \& 2}$ Department of Vocational Teacher Education, University of Nigeria, Nsukka. \\ 3Department of Adult Education and Extra-Mural Studies, University of Nigeria, Nsukka \\ ${ }^{4}$ Department of Agricultural Education, University of Agriculture, Makurdi, Nigeria.
}

\begin{abstract}
This study identified occupational competencies required by retirees in pawpaw production and makerting for sustainable livelihood in Enugu State, Nigeria. Three research questions and three hypotheses guided the study. Descriptive survey research design was used for the study. The population for the study was 320. The entire population was used for the study. A 48-item questionnaire was used for data collection. The instrument was validated by three experts. Cronbach Alpha reliability method was used to determine the internal consistency of the instrument. A reliability coefficient of 0.86 was obtained. Three hundred and twenty copies of the questionnaire were administered to the respondents by the researchers with the help of research assistants. All the administered copies of the questionnaire were retrieved and analyzed using mean, standard deviation and $t$ - test. It was found that retirees required 19 competencies in pawpaw nursery, 17 competencies in establishment and management of pawpaw orchard and 11 competencies in harvesting and marketing of pawpaw pods. It was recommended that the identified competencies be package into training modules among others for capacity-building of retirees.
\end{abstract}

Keywords: Production, Nursery, management, marketing, occupation, retiree, competencies.

\section{Introduction}

Pawpaw, Carica papaya, is one of the major popular and economic fruit vegetable crop grow in tropical and sub-tropical zones of the world. Manshardt (1992) said that pawpaw is widely believed to have originated from Caribbean Coast of Central America ranging from Argentina and Chile to Southern Mexico. It belongs to the family of cariceae with four genera which include carica, cylicomorpha, jarilla and jacaratia. The author stated that carica is the only member of the caricaceae that is cultivated as a fruit tree while others are grown primarily as ornamentals. Morton (1987) observed that pawpaw grows best in a well drained, well aerated and rich organic matter soil with PH 5.5 - 6.7. According to the author, pawpaw tree is fast - growing and prolific in nature; it produces its first fruit in $10-14$ months from germination, taking about 5 months to develop.

Nutritionally, Somsri and Bussabakoruku (2007) stated that pawpaw fruit consists mainly of water and carbohydrate, low in calories, rich in vitamins A, C, ascorbic acid and minerals such as potassium. Pawpaw is consumed as fruit vegetable, jams pickles or desserts. The author further stated that unripe pawpaw fruit is used in cooking; cooked as a vegetable; it fermented into sauerkrautor candied. Medically, Martinez (2011) stated that pawpaw fruit has been used as an ethnomedicine for centuries. Ripe pawpaw is an effective medicine for ringworm, due to its anthelmintic properties. The unripe green fruit is an aphrodisiac and lowers blood pressure. Its gummy milk sap kills parasite, controls termite, kills worm and serves as a de - wormer because of its purgative actions. The author continued that the green leaves have protective properties against malaria; when steamed and eaten like a vegetable serves as a heart tonic, analgestic and treats stomach-ache. Amer, Goldfarb, Rachmilewitz and Fibach (2008) clarified that antioxidants in pawpaw prevents a number of health conditions such as cardiovascular diseases, aging, caner, atherosclerosis and diabetic heart diseases. Eating ripe pawpaw helps to maintain the levels of blood glucose, and ensures a steady supply of glucose and high levels of energy all day. Emeruwa (1982) stated that pawpaw fruit and its extracts have produced bactericidal activity against staphylococlus aureus, Baccilus cereus, Eschanchia coli, Pseudomonas aeruginosa and shigella Flexneri.

In Enugu State, pawpaw is consumed as a fruit vegetable; the leaves are used against malaria and the stems are used as feed for pigs. For this reasons, pawpaw has market in the locality and could engage retirees for sustenance. Olaitan, Ifeanyieze and Omeje (2008) stated that retirees are individuals that have disengaged from their initial employment after a long service but are still able and willing to continue their existence in any desirable but less strenuous occupation. Jerry (2000) emphasized that re -engagement of the retirees in a sustainable occupation requires some retirement plans to help provide a liveable income when a person stops working. Some of these plans, according to the author, include government - sponsored retirement plans and 
individual savings plans. The retirees in Enugu State can continue to sustain their livelihood if they are trained and guided to invest part of their savings or pension on viable and bankable occupations like pawpaw production and marketing.

Production as explained by Jhingon in Uko (2003) is the rational combination of various input resources in order to create a stipulated output. It is the process of creating an output and making it get to the final consumers. Iwena (2008) referred to production as all economic activities which result in the creation of goods and services to certify human wants. Anyamouocha (2001) asserted that production is only said to be completed when the product gets to the final consumers. Ereboh (1995) categorized activities in crop production into preplanting, planting, post planting and harvesting operations. Therefore, pawpaw production is the combination of resource inputs for the purpose of obtaining pawpaw pods as outputs and making them available to the final consumers. The activities in pawpaw production are grouped into nursery, establishment and management of paw orchard and marketing of pawpaw pods.

Nursery is explained by Bridaine (1989) as a house or place where young plants know as seedlings are raised. It is an enclosure such as polypots, seed boxes or beds where seeds are raised into seedlings and protected from harsh weather before they are transplanted to the main farm. Asogwa (2011) observed that seedlings in the nursery are easily protected from weeds, pests and disease attacks. They grow faster due to effective utilization of fertilizers and protection from adverse weather conditions at this delicate stage of the plant. The author added that good nursery practices facilitate survival and establishment of seedlings in the farm after transplanting which makes their management easier for crop farmers.

Management, in the submission of Osinem (2008) is the coordination of all resources through the process of planning, organising, directing and controlling in order to attain stated objectives. Miriam in Abu (2013) viewed management as the judicious use of means to accomplish an end. It is the act of coordinating people's effort to achieve desired goals and objectives using available resources efficiently and effectively. In this context, management is the coordination of human effort and other relevant resources involved in pawpaw production and marketing of its pods for economic benefits.

Marketing is a means through which products are made available and sold to buyers at an agreed price. Hoyt (1995) referred to marketing as the various activities by which products are supplied, advertised and sold to the consumers. Andrew (2007) stated that agricultural marketing covers the services involved in moving an agricultural product from the farm to the consumer. It includes numerous interconnected activities such as planning production, growing and harvesting, grading, packing, transport, storage, agro- and food processing, distribution, advertising and sale of farm produce. Iwena (2008) explained that marketing of agricultural products does not only involve the disposal of agricultural produce to consumers but also the purchasing of farm inputs such as seeds, fertilizers, piglets and so on. George (2008) maintained that marketing is the most critical consideration in a crop production enterprise. The author cautioned that growers should not grow what they cannot sell, since horticultural crops are highly perishable. Marketing, in this study, involves all the activities in sourcing, grading, packing, transport, storage, distribution, advertising and selling of pawpaw pods to consumers or wholesalers. The nutritional values and perishable nature of pawpaw makes its production and marketing a profitable occupation for interested individuals.

An occupation, in the opinion of Olaitan (2001) is one's regular, daily and immediate business or job through which one earns a living or livelihood. Okorie (2000) stated that an individual who has occupation is said to have work, and that effective work of an individual worker in any occupation is based on interest, knowledge, skills, ability, attitude and value. This implies that the success of the retirees in pawpaw production and marketing occupation is based on the level of their competencies in the activities involved.

Competence, in the submission of Grove (1993), is the quality or state of being functionally adequate or having knowledge, skill or strength for a particular duty or respect. Olaitan (2003) stated that to be competent implies that an individual has acquired the knowledge, skills, attitude and judgement which he required in order to perform successfully at a specified proficiency level in a given work. In the context of this study, occupational competencies refer to the knowledge, skills, attitude and judgement that should be acquired and performed by retirees for success in pawpaw production and marketing for sustainable livelihood.

In the observation of Amusa and Dumbiri (2010), most retirees lack basic occupational competencies for self re-engagement after service. As a result, they associate fear with livelihood challenges on retirement. Jerry (2009) clarified that the fear of life on retirement is due to lack of productive competencies. In Enugu state, the researchers observe that most retirees are frequently depressed by the uncertainty of how to continue to make sustainable livelihood on retirement. The majority of them, therefore, end up in highly strenuous and flexible business with high level of risks of failure which in most cases lead to hypertension and in extreme cases death of the individual. Meanwhile, Enugu State FADAMA 111 (2010) reported that most women in Agriculture and retirees have indicated interest in pawpaw production occupation because pawpaw thrives well in the state while its supply to the market is lower than the demand by consumers and marketers who export it outside the state. The report ascertained that there is no known or registered pawpaw plantation in the state; the 
little quantity of pawpaw pods supplied to the market is harvested from wild pawpaw trees. Meanwhile, the above report implies that the effort of teachers of Agricultural science on students has not been effective in Enugu State.

Teachers of agriculture are individuals that have been trained professionally to impart knowledge, skills and attitudes to students in the art of growing crops, rearing animals and processing them for man's use. The duties of the teacher also include assessment of students' performance in class instruction, processing the scores and storing them for future use (Olaitan, Alaribe and Mohammed, 2011). The duties of teachers of agricultural science in schools include imparting knowledge and skills to students in various areas of agriculture such as crop production, soil science, animal science, forestry, fisheries and agricultural management; stimulating students' interest to participate in agricultural activities in the school and encouraging students to promote the growth and development of agriculture in the school through co-operative and clubs among others (Olaitan and Mama, 2001). The impact of the aforementioned responsibilities of teachers of Agricultural science in the society is most observed if the secondary school leavers are able establish and manage either animal or crop farms especially with the help of agricultural extension agents.

Agricultural extension agents, in the opinion of Nagel (1997), are professionals who assist farmers through educational procedure, in improving farming method and techniques, increasing production efficiency and income, bettering their levels of living and lifting social and educational standards. The author further explained that extension agents provide assistance to farmers to help them identify and analyzed their production problems and become aware of the opportunity for improvement. Davis (2008) opined that extension agents are individuals set to support and facilitate people engaged in agricultural production to solve problems and obtain information, skills and technologies to improve their livelihoods and well-being. It was in the expectation of the researchers that the extension agents could train individuals such as retirees to establish and manage pawpaw production and marketing business for sustainable livelihood but no such record exists.

Besides, there is no evidence on available literature that competencies in pawpaw production and marketing have been identified. Also, a visit by the researchers to skill acquisition centres revealed that there is no identified competency or a competency packaged programme in pawpaw production and marketing for training of interested individuals in the state. The purpose of this study was, therefore, to identify occupational competencies required by retirees in pawpaw production and marketing for sustainable livelihood in Enugu State, Nigeria. Specifically, the study sought to identify competencies required by retirees in:

1. pawpaw nursery.

2. establishment and management of pawpaw orchard

3. harvesting and marketing of pawpaw pods.

\section{Research Questions}

The following research questions guided the study.

1. What are the competencies required by retirees in pawpaw nursery?

2. What are the competencies required by retirees for the establishment and management of pawpaw orchard?

3. What are the competencies required by retirees in harvesting and marketing of pawpaw pods?

\section{Hypotheses}

The following null hypotheses were formulated for the study and tested at 0.05 level of significance.

1. There is no significant difference in the mean ratings of teachers of Agricultural science and Extension Agents on competencies required by retirees in pawpaw nursery.

2. There is no significant difference in the mean ratings of teachers of Agricultural science and Extension Agents on competencies required by retirees for establishment and management of pawpaw orchard.

3. There is no significant difference in the mean ratings of teachers of Agricultural Science and Extension agents on competencies required by retirees for harvesting and marketing of pawpaw pods.

\section{Methodology}

Three research questions and three hypotheses guided this study. Descriptive survey research and functions of industry designs were adopted for this study. Olaitan, Ali, Eyo and Sowande (2000) stated that descriptive survey research design is a plan, structure and strategy that an investigator adopts in order to obtain solution to research problems using questionnaire in collecting, analyzing and interpreting the data. Olaitan, Nwachukwu, Onyemachi, igbo, and Ekong (1999) stated that functions of industry design is one in which development of a training programme is derived from the basic functional area of an industry. These designs are suitable because the study made use of questionnaire developed from literature and functions of industry to collect data from the respondents. 
The area of the study was Enugu State. The population for the study was 320 made up of 281 teachers of agricultural science in senior secondary schools (Post Primary School Management Board, 2012) and 49 extension agents (Enugu State Agricultural Development Project, ENADEP, 2012). The entire population was used for the study because the size was small and manageable. Hence, there was no sampling.

The instrument for data collection was 48-item questionnaire titled: Pawpaw Production and Marketing Competency Questionnaire (PPMCQ). The questionnaire was developed from literature and industries by the researchers and used for data collection. The competency items had a 4 - point response scale of Highly Required, Averagely Required, Slightly required and Not required, with corresponding value of 4, 3, 2 and 1. The instrument was face - validated by five university lecturers: two from Department of Agricultural Education and one from Department of Agricultural Extension, university of Agriculture, Makurdi and two from the Department of Vocational Teacher Education, University of Nigeria, Nsukka. Their corrections and suggestions were utilized to improve the initial copies of the questionnaire to produce the final copies. Split half technique and Cronbach Alpha reliability method were adopted to determine the internal consistency of the questionnaire items. A Cronbach Alpha coefficient of 0.86 was obtained. Three hundred and twenty copies of the questionnaire were administered to the respondents, but three hundred and fourteen copies were returned and analyzed. Weighted mean and standard deviation were used to answer the research questions while $t-$ test statistic was used to test the hypothesis at 0.05 level of significance and at 312 degree of freedom. The average mean of 2.50 was used for decision - making. Any item with a mean rating of 2.50 or above was regarded as a competency item that is required while any competency item with a mean rating less than 2.50 was regarded as not required. Any item with a standard deviation between 0.00 and 1.96 indicated that the respondents were not far from the mean and the opinion of one another. The hypotheses of no significant deference was upheld for any item whose $t$ - calculated value was less than the $t$ - table value at 0.05 level of significance and at 312 degree of freedom.

\section{Results}

The results for the study were obtained from the research questions answered and hypotheses tested through data collected and analyzed.

\section{Research Question 1}

What are the competencies required by retirees in pawpaw nursery?

\section{Hypothesis 1}

There is no significant difference in the mean ratings of teachers of Agricultural science and Extension Agents on competencies required by retirees in pawpaw nursery.

The data for answering research question 1 and testing hypothesis 1 are presented in Table 1 .

Table 1: Mean Ratings, Standard Deviation and $t$ - test Analysis of the Responses of Teachers of Agricultural Science and Extension Agents on Competencies Required by Retirees in Pawpaw Nursery. $(\mathrm{N}=312)$

\begin{tabular}{|c|c|c|c|c|c|}
\hline $\mathbf{N} / \mathbf{S}$ & Competencies in Nursery. & $\mathbf{X}$ & SD & t-cal & Remark \\
\hline 1. & Select site with vegetation shed and free from flooding. & 3.13 & 1.36 & 0.76 & RQ, NS \\
\hline 2. & Clear and remove vegetation from the site & 3.16 & 1.85 & 0.62 & RQ, NS \\
\hline 3. & Mark out the site in rows leaving a space of $2 \mathrm{~m}$ in between them. & 3.26 & 1.79 & 0.50 & RQ, NS \\
\hline 4. & $\begin{array}{l}\text { Provide material inputs such as baskets, poly bags or trays, garden } \\
\text { soil, river sand, organic manure, hoe or shovel. }\end{array}$ & 3.18 & 1.90 & 0.59 & RQ, NS \\
\hline 5. & $\begin{array}{l}\text { Mix garden soil, river sand and organic manure in the ratio of } 3: 2: 1 \\
\text { thoroughly with shovel }\end{array}$ & 3.09 & 1.3 & 0.36 & RQ, NS \\
\hline 6. & $\begin{array}{l}\text { Fill the available container (basket, poly bag or tray) with the } \\
\text { mixture. }\end{array}$ & 2.99 & 1.04 & 0.37 & RQ, NS \\
\hline 7. & $\begin{array}{l}\text { Arrange the filled container along } 4 \text { rows or more lines with } 40 \mathrm{x} \\
45 \mathrm{~cm} \text { square spacing. }\end{array}$ & 3.08 & 1.31 & 0.69 & RQ, NS \\
\hline 8. & Water the container with its content daily to make the mixture wet. & 2.86 & 1.21 & 0.55 & RQ, NS \\
\hline 9. & $\begin{array}{l}\text { Select seeds of exotic varieties such as pink solo, kapolo solo, JS. } 22 \\
\text { etc. }\end{array}$ & 3.18 & 1.86 & 0.53 & RQ, NS \\
\hline 10. & $\begin{array}{l}\text { Scrub the seeds slightly in a bucket with sand to remove the } \\
\text { gelatinous covering for quick germination. }\end{array}$ & 3.14 & 1.86 & 0.63 & RQ, NS \\
\hline 11. & $\begin{array}{l}\text { Mix the slurry of sand with water to separate good speeds from bad } \\
\text { ones. }\end{array}$ & 3.12 & 1.37 & 0.77 & RQ, NS \\
\hline 12. & Remove bad seeds which float on water in the bucket. & 3.10 & 1.15 & 0.70 & RQ, NS \\
\hline 13. & Drain water from the bucket to remove the goods seeds. & 2.98 & 1.23 & 0.64 & RQ, NS \\
\hline 14. & Spread out the good seeds in the shed to air - dry them. & 3.08 & 1.12 & 0.49 & RQ, NS \\
\hline 15. & $\begin{array}{l}\text { Sow the seeds in the container (basket, poly bag or tray) earlier } \\
\text { prepared. }\end{array}$ & 3.03 & 1.14 & 0.39 & RQ, NS \\
\hline 16. & Water the container with its content every other day. & 3.02 & 1.94 & 0.94 & RQ, NS \\
\hline 17. & Observe seeds for germination after 2 weeks of planting. & 3.19 & 1.84 & 0.44 & RQ, NS \\
\hline
\end{tabular}




\begin{tabular}{|c|c|c|c|c|c|}
\hline 18. & $\begin{array}{l}\text { Remove shade if provided with palm fronds to 'harden' the } \\
\text { seedlings. }\end{array}$ & 3.12 & 1.92 & 0.47 & RQ, NS \\
\hline 19. & $\begin{array}{l}\text { Transplant pawpaw seedlings after about } 6 \text { weeks of planting to the } \\
\text { farm, or market seedling for sale. }\end{array}$ & 3.13 & 1.88 & 0.53 & QR, ND \\
\hline & Grand total & 3.10 & 1.53 & $\mathbf{0 . 5 8}$ & QR, ND \\
\hline
\end{tabular}

$\mathrm{X}=$ mean, $\mathrm{SD}=$ standard deviation, $\mathrm{t}$-cal $=\mathrm{t}$ - calculated, $\mathrm{t}$ - table $=1.96, \mathrm{RQ}=$ Required, NS $=$ Not significant.

The data in Table 1 revealed that the mean of the 19 items and grand mean ranged from 2.86 to 3.26.

This showed that each and all of the items had a mean value above the cut off point of 2.50 which indicated that all the competencies were required by retirees for pawpaw nursery. The Table also revealed that each and all of the items had their standard deviation ranged from 1.03 to 1.94; this showed that the respondents were not far from the mean and from one another in their responses. The result of the test of hypothesis in table 1 indicated that each of the items had its calculated $t$ - value lower than the table value of 1.96. This revealed that there was no significant difference in the mean ratings of teachers of Agricultural science and extension agents on competencies required by retirees on pawpaw nursery. Therefore, the hypothesis of no significant difference was upheld for the 19 items.

\section{Research Question 2}

Hypothesis 2

What are the competencies required by retirees on establishment and management of pawpaw orchard?

There is no significant difference in the mean ratings of teachers of Agricultural science and Extension Agents on competencies required by retirees in establishment and management of pawpaw orchard.

The data for answering research Question 2 and testing hypothesis 2 are presented in Table 2.

Table 2: Mean Ratings, Standard Deviation and $\mathrm{t}$ - test Analysis of the Responses of Teachers of Agricultural Science and Extension Agents on Competencies Required by Retirees in Establishment and Management of Pawpaw Orchard. $(\mathrm{N}=312)$.

\begin{tabular}{|c|c|c|c|c|c|}
\hline $\mathbf{S} / \mathbf{N}$ & Competencies in Establishment and Management. & $\mathbf{X}$ & SD & t-cal & Remarks \\
\hline 1. & $\begin{array}{l}\text { Select pawpaw orchard site of well drained soil (preferably loam soil) and free } \\
\text { from water logging. }\end{array}$ & 3.06 & 0.78 & 0.43 & RQ, NS \\
\hline 2. & Survey the land for proper demarcation. & 3.12 & 0.90 & 0.61 & RQ, NS \\
\hline 3. & Clear the vegetation and remove the debris and stumps. & 3.48 & 0.74 & 0.84 & RQ, NS \\
\hline 4. & Plough and harrow the site to pulverize the soil for easy root development. & 3.36 & 0.81 & 0.84 & RQ, NS \\
\hline 5 . & $\begin{array}{l}\text { Mark the site in rows using pegs and leaving a space of } 4 \mathrm{~m} \text { after planting } 10 \\
\text { rows to allow for movement of equipment. }\end{array}$ & 3.61 & 0.91 & 0.56 & RQ, NS \\
\hline 6. & Make holes of $15 \mathrm{~cm}-20 \mathrm{~cm}$ deep and $2 \times 2 \mathrm{~m}$ spacing (ie between 2 holes). & 3.44 & 0.76 & 0.81 & RQ, NS \\
\hline 7. & $\begin{array}{l}\text { Transplant } 1 \text { or } 2 \text { seedlings per hole when using a dioecious variety to ensure a } \\
\text { high female survival. }\end{array}$ & 3.03 & 0.67 & 0.87 & RQ, NS \\
\hline 8. & Remove the poly bag from the hole and cover it with garden soil. & 3.94 & 1.03 & 0.59 & RQ, NS \\
\hline 9. & $\begin{array}{l}\text { Affirm / consolidate the soil at the base of the seedling ensuring that they are in } \\
\text { upright position. }\end{array}$ & 3.55 & 0.54 & 0.62 & RQ, NS \\
\hline 10. & Water the orchard if rain has not stabilized. & 3.48 & 0.74 & 0.70 & RQ, NS \\
\hline 11. & $\begin{array}{l}\text { Apply } 50 \mathrm{~g} \text { of NPK } 15-15-15 \text { per plant / hole } 3 \text { weeks after planting (based in } \\
\text { soil test). }\end{array}$ & 3.34 & 0.79 & 0.47 & RQ, NS \\
\hline 12. & Repeat fertilizer application at monthly intervals up to 6 months after planting. & 3.66 & 0.57 & 0.89 & RQ, NS \\
\hline 13. & $\begin{array}{l}\text { Weed the orchard manually with hoe or cutlass or chemically using herbicide } \\
\text { paraquat glyphosate at } 4-6 \text { or } 3 \mathrm{~kg} \text { active ingredient per hectare at monthly } \\
\text { interval depending on the fertility of the soil. }\end{array}$ & 3.70 & 0.52 & 0.62 & RQ, NS \\
\hline 14. & $\begin{array}{l}\text { Apply } 3 \text { litres of water per plant twice a week for new seedlings, } 5 \text { litres twice a } \\
\text { week for flowering plant, } 15 \text { litres per plant once a week for fruit bearing plant. }\end{array}$ & 2.78 & 0.06 & 0.32 & RQ, NS \\
\hline 15. & $\begin{array}{l}\text { Interplant pawpaw with early maturing plants like okra, leafy vegetable, melon, } \\
\text { sweet potato or sweet, corn. }\end{array}$ & 2.72 & 0.79 & 0.45 & RQ, NS \\
\hline 16. & $\begin{array}{l}\text { Apply teaspoonful of furaden per seedling to control nematode or Gamalin } 20 \text { at } \\
15 \mathrm{mls} / 10 \text { litres of water for grasshoppers at } 3 \text { weeks after transplanting. }\end{array}$ & 3.11 & 1.22 & 0.70 & RQ, NS \\
\hline \multirow[t]{2}{*}{17.} & Harvest mature pawpaw pods at 'blush stage' using colour change. & 3.92 & 1.04 & 0.55 & RQ, NS \\
\hline & Grand total & 3.37 & 0.76 & 0.64 & RQ, NS \\
\hline
\end{tabular}

$\mathrm{X}=$ mean, $\mathrm{SD}=$ standard deviation, $\mathrm{t}$-cal $=\mathrm{t}$ - calculated, $\mathrm{t}-$ table $=1.96, \mathrm{RQ}=$ Required, $\mathrm{NS}=$ Not significant.

The data in Table 2 revealed that the mean of the 17 items and the grand mean ranged from 2.72 to

3.94. This showed that each and all of the items had a mean value above the cut off point of 2.50 which indicated that all the competencies were required by retirees for establishment and management of pawpaw orchard. The Table also revealed that each and all of the items had their standard deviation ranged from 0.43 to 1.22; this showed that the respondents were not far from the mean and from one another in their responses. The result of the test of hypothesis in Table 2 indicated that each of the items had its calculated $t$ - value lower than the table value of 1.96. This revealed that there was no significant difference in the mean ratings of teachers of Agricultural Science and Extension agents on the competencies required by retirees in establishment and management of pawpaw orchards. Therefore, the hypothesis of no significant difference was upheld for the 17 items. 


\section{Research Question 3}

What are the competencies required by the retirees for harvesting and marketing of pawpaw pods?

\section{Hypothesis 3}

There is no significant difference in the mean ratings of teachers of Agricultural Science and Extension agents on competencies required by the retirees for harvesting and marketing of pawpaw pods. The data for answering research question 3 and testing hypothesis 3 are presented in Table 3 .

Table 3: Mean Ratings, Standard Deviation and $t$ - test Analysis of the Responses of Teachers of Agricultural Science and Extension Agents on Competencies Required by Retirees for Harvesting and Marketing of Pawpaw Pods. ( $\mathrm{N}=312$ ).

\begin{tabular}{|c|c|c|c|c|c|}
\hline $\mathbf{N} / \mathbf{S}$ & $\begin{array}{l}\text { Harvesting and Marketing of Pawpaw Pods. } \\
\text { Competencies in Harvesting }\end{array}$ & $\mathbf{X}$ & SD & t- cal & Remarks \\
\hline 1. & $\begin{array}{l}\text { Determine at what stage of maturity to harvest pawpaw pods based on the } \\
\text { market channel. }\end{array}$ & 3.52 & 0.72 & 1.04 & RQ, NS \\
\hline 2. & $\begin{array}{l}\text { Move round the orchard to identify mature pods using colour change from } \\
\text { green to light green, tinge of yellow or red at the apical end depending on } \\
\text { the variety. }\end{array}$ & 3.76 & 1.01 & 0.84 & RQ, NS \\
\hline 3. & $\begin{array}{l}\text { Place a leader on the pawpaw tree and climb it to reach to the pods if the } \\
\text { stem is tall. }\end{array}$ & 2.94 & 1.43 & 0.76 & RQ, \\
\hline 4. & $\begin{array}{l}\text { Pick pawpaw pods by holding it in the palm and twisting it to cut the fruit } \\
\text { stalk. }\end{array}$ & 3.90 & 1.21 & 0.48 & RQ, \\
\hline 5. & $\begin{array}{l}\text { Bring pawpaw pods down carefully to avoid wound or bruises on the } \\
\text { surface which quickens ripening and decay of the pod }\end{array}$ & 3.70 & 1.23 & 0.64 & RQ, \\
\hline 6. & $\begin{array}{l}\text { Keep pawpaw pods on dry surface in a cool and ventilated shed or room } \\
\text { Competencies in Marketing }\end{array}$ & 3.06 & 0.80 & 0.94 & RQ, NS \\
\hline 7. & Sort and grade pawpaw pods using sizes, colour and variety. & 3.82 & 0.66 & 0.56 & RQ, NS \\
\hline 8. & Fix appropriate prices for each grade based on market survey or demand. & 3.21 & 0.77 & 0.98 & RQ, \\
\hline 9. & Advertise pawpaw pods locally or through the media to attract buyers. & 3.64 & 0.93 & 0.60 & RQ, \\
\hline 10. & $\begin{array}{l}\text { Sell pods direct to buyers at the orchard gate or transport the pods to market } \\
\text { for sale at better price. }\end{array}$ & 2.52 & 0.79 & 0.50 & RQ, \\
\hline 11 & Distribute or sell pods to consumers through middlemen & 3.60 & 0.83 & 0.66 & RQ, NS \\
\hline 12. & Keep appropriate records of sales for sustainability and/or expansion. & 3.64 & 0.33 & 1.14 & RQ, NS \\
\hline \multirow[t]{2}{*}{13.} & Calculate the expenditure and income to balance the profit or loss account. & 2.74 & 0.43 & 0.95 & RQ, NS \\
\hline & Grand total & 3.39 & 0.86 & $\mathbf{0 . 7 8}$ & RQ, NS \\
\hline
\end{tabular}

$\mathrm{X}=$ mean, $\mathrm{SD}=$ standard deviation, $\mathrm{t}-\mathrm{cal}=\mathrm{t}$ - calculated, $\mathrm{t}-$ table $=1.96, \mathrm{RQ}=$ Required, $\mathrm{NS}=$ Not significant.

The data in Table 3 revealed that the mean of each the 12 items and the grand mean ranged from 2.52 to 3.90. This showed that each of the items had a mean value above the cut off point of 2.50 which indicated that all the competencies were required by retirees in harvesting and marketing of pawpaw pods. The Table also revealed that each and all of the items had their standard deviation ranged from 0.33 to 1.43 ; this showed that the respondents were not far from the mean and from one another in their responses. The result of the test of hypothesis in Table 3 indicated that $t$-value of each and all of the items are lower than the table value of 1.96. This revealed that there was no significant difference in the mean ratings of teachers of agricultural science and extension agents on the competencies required by retirees for harvesting and marketing of pawpaw pods. Therefore, the hypothesis of no significant difference was upheld for the 12 items.

\section{Discussions of results}

The result of this study revealed that retirees required 19 competencies in pawpaw nursery. The competencies include: select site with vegetation shed and free from flooding, clear and remove vegetation from the site, mark out the site in rows leaving a space of $2 \mathrm{~m}$ in between them, provide material inputs such as baskets, poly bags or trays, garden soil, river sand, organic manure, hoe or shovel and so on. This result is in consonance with the findings of Asogwa, Uko and Omeh (2010) that teachers in oil production posses the following skills: select site for the oil palm nursery, mark out the land with pegs, provide polythene bags, perforate the polythene bags at the bottom to drain out water among others. Ukonze (2010) also found out that clearing the site ready for tillage, marking out the tilled land for beds, maintaining farm hygiene and providing shade are important skills in nursery operation for vegetable crops productionin Enugu State.

The result of the study also revealed that retirees required 17 competencies for establishment and management of pawpaw orchard. Some of the identified competencies are: select pawpaw orchard site of well drained soil (preferably loam soil) and free from water logging, survey the land for proper demarcation, clear the vegetation and remove the debris and stumps, transplant 1 or 2 seedlings per hole when using a dioecious variety to ensure a high female survival, water the orchard if rain has not stabilized and apply 50g of NPK 15 $15-15$ per plant / hole 3 weeks after planting (based in soil test). These findings are in consonance with Okorie (1985) that the steps in sowing of seeds in the garden include: dig the soil to specification, rake the soil to give a fin tilth, remove any weed, plant the seeds and cover the seeds with soil from a fine sieve. Obinne (1986) also 
corroborated that the activities in post-planting operation include: thinning, supplying, mulching, fertilizer application, irrigation, weeding, pest and disease control and harvesting. Uguru (2006) recommended that 1515-15 NPK fertilizer is good for vegetable crop production in which pawpaw is one of them.

Another result of the study was that retirees required 12 competencies in harvesting and marketing of pawpaw pods. The competencies in harvesting include: determine at what stage of maturity to harvest pawpaw pods based on the market channel, place a ladder on the pawpaw tree and climb it to reach to the pods if the stem is tall and pick pawpaw pods by holding it in the palm and twisting it to cut the fruit stalk. While competencies in marketing include: sort and grade pawpaw pods using sizes, colour and variety; fix appropriate prices for each grade based on market survey or demand; advertise pawpaw pods locally or through the media to attract buyers and distribute or sell pods to consumers through middlemen. These results are in agreement with Olaitan, Asogwa and Eze (2010) that skills in marketing of vegetable products include: cleaning vegetable products of soil, sort and grade vegetable products, store, advertise and sell the products and keep appropriate records of expenses and sales. Omeje and Asogwa (2013) found out that skills in marketing of melon seeds include: survey the market for demand of melon products, fix prices for melon per-kilogram weight, identify distributing channels, advertise melon seeds to buyers, sell melon seeds to buyer at farm site or at the market and keep sales record to calculate profit or loss for melon production. The findings and observations of the authors cited above helped to add validity to the findings of this study.

\section{Conclusion and Recommendation}

Pawpaw is a fruit vegetable highly consumed by households in Enugu State because of its nutritive and medical values. This made its demand higher than its supply in the market. Hence, pawpaw production is lucrative and bankable such that retirees can invest their little savings or pension in the occupation safely. The study found out that 48 competencies are required by retirees in pawpaw production for sustainable livelihood. Based on the findings of the study, it was therefore, recommended that:

1. Retirees in Enugu State should be trained by skill acquisition centres in pawpaw production using the identified competencies.

2. The identified competencies in pawpaw production and marketing should be developed into training modules by extension agents and administrators of skill acquisition centres for training of interested individuals especially the retirees.

3. The identified competencies should be used by extension agents to build the capacity of crop farmers in pawpaw production.

4. Secondary school graduates should be trained on pawpaw production using the identified competencies.

\section{References}

[1]. Abu, M. (2013) Management initiatives for participants in soil erosion management in the tropics. A Ph.D assignment presented to the Department of Vocational Teacher Education, University of Nigeria, Nsukka.

[2]. Amasa,T.A.and Dumbiri, D.N. (2010) Entrepreneurial skills Required by retirees for Tree crop seedling production in Ekiti State, Nigeria. Journal of Nigerian Vocational Association. Vol. 15. No. 1. Pp $386-378$.

[3]. Amer, J; Goldfarba, Rachnilewitz,Ea, Fibach, E (2008) Fermented Papaya Preparation as redox regulator in blood cells of beta thalassemic mice and patients. Phytother Res 2008 June; 22 (6) : $820-8$.

[4]. Andrew W. S (2009) Approaches to linking producers to markets. Rome: FAO.

[5]. Anyamouocha, A. G (2001) New College Economic. Ogun state: Tonad publishers Limited.

[6]. Asogwa V.C (2011) Horticulture production. Unpublished Lecture note in the The College of Education Nsukka.

[7]. Asogwa, V. C; Uko, E. O and Omeh, O. M. (2010) Quality Assurance of teachers Teaching Oil Palm Production to Students in senior Secondary Schools in Enugu State. Journal of Nigerian Vocational Association. 15(1):273-281.

[8]. Bianze, P.N. (2005) Occupation work - skill required by secondary school graduates for entry into oil palm production enterprises in Delta State. Unpublished M.Ed Thesis, University of Nigeria, Nsukka.

[9]. Bridaine, O.M. (1989) African Gardens and Orchardsi Growing vegetable and fruits. London: Kaemillian Publishers.

[10]. Davis (2008). Extension of sub-Shara Africa Overview and Assessment of Current Models and future. Retrieved from http?//majorcrop.net/family/memos/P-Trevin 0n 5/7/2010.

[11]. Egbe, B.O. and Eze, S. O (2010) Identification of occupational work - skills needed in oil palm production for Training secondary school graduates in skill Acquisition Centres in Ebonyi State. Journal of Ebonyi Technology and Vocational Education Vol 1: N0 1: $185-190$.

[12]. Ejiofor, (2010) Work - skills required by secondary school graduates for such success in cassava production Enterprises. Journal of Home Research Economics. Vol. 12:62 - 71 .

[13]. Emerwa, A.C (1982) Antibacterial substance from Carica papaya fruit extract. Journal of Natural Products .45:123 -127.

[14]. Erebor, C. (1995) Comprehensive Agricultural Science for Senior Secondary Schools. Onitsha: Johnson Publishing Ltd.

[15]. FADAMA (2010) A list of common crops grown in Enugu. Unpublish weekly report Enugu State.

[16]. George A. (2009), Horticulture: Principles and Practices. India: Pearson Education, Inc.

[17]. Gove, P.B (1993) Webster's Third New International Dictionary of English Language Unabridged. USA :Marriam Webster.

[18]. Hoyt, L.J. (1995) Competencies in livestock Marketing needed by farmers. Lowa: University Press.

[19]. http://@europe.eu/agriculture/public/caprep/prospects.

[20]. Iwena, O.A (2008). Essential Agricultural Science for Se schools. Ogun state. Toand publishers limited.

[21]. Jerry S.R. (2009) Retirement Plan. Retrieved on July10, 2010 from http://www.hodc.drh.ca/isp/common.

[22]. Manshoodf, R.M. (1992) Papaya. Hammershschlag FA,litz RE (Eds) Biotechnology in Agriculture No 8. Biotechnology of Peremmial Fruit Crops, CABI, Wallingford, PP489 - 511. 
[23]. Martines, P (2011) Papaya can Treat Malaria and Termites. Retrieved from http://fruit - crops.com/papaya/on 13/04/12.

[24]. Morton, J.F.(1987) Papaya. Morton J.F.(ED) Fruit of worm climates, creative Resources Systems, Inc Miami F1 PP336 - 346.

[25]. Nagel, U, J. (1997). Alternative Approaches to Organizing Extension, in Swanson B. Improving Agricultural Extension. A Reference Manual $3^{\text {rd }}$ Edition F.A.O.

[26]. Obinne, C.P. (1986) Agricultural Science for Secondary schools. Nenin City. Does-Sun Publishers

[27]. Okorie, J. U. (1985). Junior Tropical agriculture Macmillan publisher ltd. London and basing stoke

[28]. Okorie, J.U. (2000) Developing Nigeria's workforce. Calabar: Macnky Environs Publishers Nigeria.

[29]. Olaitan, S. O; Alaribe, M. O. and Mohammed, D. I.(2011) Competency capacity building needs of teachers of agriculture in utilizing e-assessment for processing and storing Students Performance Scores in Junior Secondary Schools in Enugu State. A paper presented at the Annual Conference of the Institute of Education, University of Nigeria, Nsukka.

[30]. Olaitan, S.O. (2003) Understanding Curriculum. Nsukka: Ndudum Printing and Publishing Company.

[31]. Olaitan, S.O. and Mama, R.O. (2001) Principles and practices of school Farm Management. Enugu: Nigeria; Cape Publishers Int'I Ltd.

[32]. Olaitan, S.O; Ifeanyieze, F.O. and Omeje, J.C (2008) Micro - livestock (Bee keeping) for Reengagement of Retirees in a sustainable occupation in Enugu State. A journal of Agriculture and social sciences. Vol 4. Pp $153-158$.

[33]. Olaitan,S.O, Asogwa, V.C and Eze, S.O (2011) Entrepreneurial skill capacity building needs of instructors in range and pasture management for effective teaching of students of Animal Production in schools of Agriculture in Southeast, Nigeria. Journal of Nigeria Educational Research Association. 16(1): 105-114.

[34]. Omeje, N. M. and Asogwa, V. C. (2013) Resource Management Skill Improvement Needs of Women Farmers in Melon Production for Poverty Reduction in Enugu State, Nigeria. International Journal of Agriculture Innovations and Research. 2(1), $2319-1473$. India \& Asia. www.ijair.org

[35]. Osinem, E. C. (2008). Managing Agricultural Education and Training. Resources

[36]. Principles and Methods. Enugu: Betony International Publishers.

[37]. Somsri, S and Bussabakornkul, S (2007) Identification of certain Papaya cultivars and sex identification in Papaya by DNA amplification fingerprinting (DAF). Acts Horticulture 738: 171 -182.

[38]. Uguru M. I (2006) Crop production, Tools Techniques and practice. Enugu: Fulladu publishing company.

[39]. Uko, E.O. (2003) Development of job Entry level skills in Poultry Production for students in Senior Secondary Schools in Akwa Ibom State. Unpublished M.Ed thesis submitted to the Department of Vocational Teacher Education, University of Nigeria, Nsukka.

[40]. Ukonze, J. A (2010) Vegetable Production Skills Needed by Instructors in Universities for Effective Teaching of Vegetable Crops in Enugy state. Nigerian Vocational Association Journal 15(1),63-71.

[41]. Uwadi, N. (2006) Competencies required in small scale Commercial poultry Production to enhance the livelihood of urban operators in Abia State. Unpublished M. Ed Thesis, Department of Vocational Teacher Education, University of Nigeria, Nsukka.

\section{Biographies}

Ernest O. Ugwoke has Ph.D Degree, a lecturer in the Department of Vocational Teacher education, University of Nigeria, Nsukka and a professional Business Educator with specialization in Accounting Education. He has many articles published to his credit in reputable international journals.

Francis M. Onu has Ph.D in Agricultural Education. He is a senior lecturer in the Department of Vocational Teacher Education, University of Nigeria, Nsukka. He has many books and journal article publications to his credit.

Matthias U. Agboeze is a lecturer in the Department of Adult Education and Extra-Mural Studies, University of Nigeria, Nsukka and he is a specialist in Adult Education and Community Development. He has many journal article publications to his credit.

Vincent C. Asogwa is a lecturer in Department of Agricultural Education, University of Agriculture, Makurdi, Nigeria. He has published many articles in reputable journals. 